\title{
FORTIFIKASI GUAVA (Psidium guajava L.) JELLY DRINK DENGAN ZAT BESI ORGANIK DARI KEDELAI (Glycine max L.) DAN KACANG HIJAU (Vigna radiate L.)
}

Guava (Psidium guajava L.) Jelly Drink Fortification from Organic Iron from Soybean (Glycine max L.) and Mungbeans (Vigna radiate L.)

\author{
Christina Hanny Setyaningrum ${ }^{1) *}$, Ivone Elizabeth Fernandez ${ }^{1)}$, \\ Robertus Probo Yuliato Nugrahedi ${ }^{1)}$ \\ ${ }^{1)}$ Jurusan Teknologi Pangan - Fakultas Teknologi Pertanian, Universitas Katolik Soegijapranata \\ Jalan Pawiyatan Luhur IV / 1 Bendan Dhuwur, Semarang \\ *E-mail: hanny3395@gmail.com
}

\begin{abstract}
Anemia is a condition of haemoglobin level that is below normal. One of the major causes is lacking of iron consumption, which is important in haemoposis process. Compared to men, women have less total iron in the body, and it raises the risk of anemia. The main purpose of this research was the fortification of iron in beverage. This research used soybean and mungbean as source of iron, which known as non-heme iron. To improve the absorption, ascorbic acid was needed as an enhancer, using guava and was produced into guava jelly drink. Method for extraction process is by maseration with $30 \%$ etanol as solution. The value of iron extract assessed by AAS at 248,3 $\mathrm{nm}$. The formula of fortification was 20\% of RDA of iron for woman, which was $18 \mathrm{mg}$ per day. Chosen product was evaluated by sensory test. The nutrition value of product assessed including iron content, ascorbic acid, and proximate composition. The iron content of soybean was 113,86 ppm and 58,76 for mungbean. The nutrition of guava jelly drink with addition of fortificant were $87,47 \%$ water, $0,35 \%$ ash, 0,2\% fat, 0,31\% protein, 11,67\% carbohydrate, 130,48 ppm iron, and 90,79 $\mathrm{mg}$ ascorbic acid.
\end{abstract}

Keywords: iron deficiency anemia, soy bean, mungbean, jelly drink, and guava

\section{PENDAHULUAN}

Berdasarkan data World Health Organization (WHO) pada tahun 2014 diketahui bahwa prevalensi anemia remaja putri di Indonesia sebesar 26\%. Anemia merupakan suatu kondisi dimana kadar hemoglobin $(\mathrm{Hb})$ dalam darah berada di bawah normal. Salah satu penyebab utama dari penyakit ini yaitu kurangnya asupan zat besi $(\mathrm{Fe})$ dalam tubuh.

Zat besi merupakan salah satu zat gizi esensial yang berperan dalam pembentukan sel darah merah. Pada wanita usia subur, anemia sering terjadi akibat adanya siklus menstruasi yang menyebabkan hilangnya darah dalam sewaktu (WHO, 2001). Anemia defisiensi besi dapat mengganggu sistem imunitas dan fungsi kognitif pada berbagai tingkatan umur. Pada usia sekolah akan mempengaruhi prestasi belajar, pada usia dewasa dapat menimbulkan kelelahan dan penurunan produktivitas, dan pada ibu hamil dapat menyebabkan bayi lahir prematur (Ruel, 2001).

Salah satu cara yang dapat dilakukan untuk mengatasi masalah ini yaitu dengan fortifikasi zat besi. Fortifikasi merupakan penambahan suatu jenis zat gizi ke dalam bahan pangan untuk mencegah defisiensi dan meningkatkan kesehatan (WHO, 2006). Dalam penelitian ini dilakukan fortifikasi zat besi organik ke dalam produk jelly drink sehingga dihasilkan 
minuman jeli yang enak dan sehat. Kedelai dan kacang hijau merupakan bahan nabati yang kaya akan zat besi. Di dalam 100 gram kedelai terkandung $15,7 \mathrm{mg}$ besi, sedangkan dalam 100 gram kacang hijau terkandung 6,74 $\mathrm{mg}$ zat besi (USDA, 2017). Proses ekstraksi zat besi dari kedelai dan kacang hijau dilakukan dengan metode maserasi dengan menggunakan pelarut etanol. Zat besi nabati tergolong sebagai besi non-heme. Zat besi non-heme memiliki tingkat penyerapan yang rendah, yaitu hanya 1-6\% (Benito \& Miller, 1998). Oleh karena itu untuk meningkatkan penyerapan zat besi non-heme, maka diperlukan konsumsi vitamin $\mathrm{C}$, salah satunya dari jambu biji merah. Penelitian ini memformulasi dan menganalisis organoleptik dan kimiawi dari puree jambu biji merah dengan penambahan fortifikan zat besi campuran dari kedelai dan kacang hijau menjadi produk guava jelly drink.

\section{METODE PENELITIAN}

\section{Alat dan Bahan}

Alat-alat yang digunakan dalam penelitian ini adalah chopper untuk mengecilkan ukuran kedelai dan kacang hijau, juicer untuk membuat puree jambu biji merah, panci untuk memasak guava jelly drink, cup ukuran $100 \mathrm{ml}$ sebagai pengemas guava jelly drink, sedangkan alat yang digunakan untuk analisa antara lain termometer, desikator, oven, kertas saring, penjepit, tanur, alat dekstruksi, alat destilasi Kjeldahl, Soxhlet, buret, statif, pipet volum, pipet tetes, pompa Pilleus, gelas arloji, beaker glass, timbangan analitik, penangas air, Atomic Absorption Spectrophotometer (AAS), labu Erlenmeyer, cawan porselen, dan corong. Bahan yang digunakan dalam penelitian ini adalah kedelai, kacang hijau, dan jambu biji merah yang diperoleh di pasar sekitar wilayah Jatingaleh Semarang.

\section{Tahapan Penelitian}

Ekstraksi zat besi (Nursuchita et al., 2014)

Kedelai dan kacang hijau dicuci dan ditimbang beratnya. Kemudian dihancurkan dengan menggunakan chopper. Ekstraksi dilakukan dengan metode maserasi etanol 30\%. Bahan dimaserasi dengan perbandingan 1:5 selama 3 hari. Ampas penyaringan kemudian dimaserasi kembali dengan etanol $30 \%$ dengan perbandingan 1:3 selama 2 hari. Filtrat hasil penyaringan pertama dan kedua diuapkan dengan menggunakan penangas air hingga didapat ekstrak kental. Kandungan zat besi dalam tiap miligram ekstrak diukur dengan metode atomic absorption spectrophotometry (AAS) pada panjang gelombang 248,3 nm.

\section{Pembuatan guava jelly drink}

Jambu biji merah dikupas dan dicuci. Selanjutnya dimasukkan ke dalam juicer sehingga dihasilkan puree. Bahan pendukung (karagenan, gula, asam sitrat, dan fortifikan zat besi) ditimbang sesuai formulasi yang telah ditentukan (Tabel 1). Pembuatan jelly drink dilakukan dengan pencampuran seluruh bahan yang dimasak hingga suhu $80^{\circ} \mathrm{C}$. Guava jelly drink dimasukkan ke dalam cup, dan didinginkan pada suhu ruang.

Tabel 1. Formulasi guava jelly drink dengan penambahan fortifikan zat besi

\begin{tabular}{lcccc}
\hline \multicolumn{1}{c}{ Bahan } & F1 & F2 & F3 & F4 \\
\hline Puree jambu biji & 50 & 50 & 50 & 50 \\
merah (ml) & & & & \\
Air (ml) & 150 & 150 & 150 & 150 \\
Gelling agent $(\mathrm{g})$ & 0,9 & 0,9 & 0,9 & 0,9 \\
Gula pasir $(\mathrm{g})$ & 20 & 20 & 20 & 20 \\
Asam sitrat (g) & 0,3 & 0,3 & 0,3 & 0,3 \\
Fortifikan (g): & & & & \\
- Kedelai & - & - & 31,61 & 15,8 \\
- Kacang hijau & - & 61,22 & - & 30,61 \\
Maltodekstrin (g) & - & 12,41 & 6,32 & 9,37 \\
\hline
\end{tabular}

Ket:

F1: guava jelly drink tanpa penambahan fortifikan

F2: guava jelly drink dengan penambahan fortifikan Fe dari kacang hijau 
F3: guava jelly drink dengan penambahan fortifikan Fe dari kedelai

F4: guava jelly drink dengan penambahan fortifikan $\mathrm{Fe}$ campuran dari kedelai dan kacang hijau

\section{Metode Analisis}

Analisis yang dilakukan pada produk guava jelly drink yaitu analisa organoleptik yang dilanjutkan dengan analisa kimiawi yang meliputi uji kadar zat besi, uji kadar vitamin $\mathrm{C}$ dan analisa proksimat. Uji organoleptik yang dilakukan merupakan uji kesukaan terhadap atribut warna, aroma, tektur, rasa, dan keseluruhan dengan 30 panelis wanita mahasiswi Universitas Katolik Soegijapranata. Panelis diminta menentukan tingkat kesukaan mereka terhadap sampel yang disajikan. Produk dengan jumlah nilai tertinggi kemudian akan dianalisis lanjut secara kimiawi.

\section{Penentuan Formula Terbaik (Indeks Efektifitas) (De Garmo et al., 1994)}

Berikut prosedur penentuan formula terbaik:

1. Menentukan bobot nilai (BN) pada masing-masing parameter dengan angka relatif $0-1$. Besar bobot ditentukan berdasarkan tingkat kepentingan parameter.

2. Bobot normal tiap parameter (BNP) ditentukan dengan rumus :

Bobot Normal Parameter (BNP)

$$
=\frac{\text { Bobot Nilai }(B N)}{\text { Bobot Nilai Total }(B N T)}
$$

3. Menghitung nilai efektivitas (NE) dengan rumus :

$N$ Efektifitas (NE)

$$
=\frac{\text { Nilai Perlakuan }- \text { Nilai Terburuk }}{\text { Nilai Terbaik }- \text { Nilai Terburuk }}
$$

4. Nilai hasil (NH) masing-masing parameter ditentukan dengan rumus: Nilai Hasil (NH)

$=N$ Efektifitas $(N E) \times$ Bobot Normal $(B N P)$
5. Nilai total semua kombinasi perlakuan dihitung dengan menjumlahkan semua nilai hasil masing-masing parameter.

6. Nilai total terbesar menunjukkan hasil perlakuan terbaik.

Uji kimia yang dilakukan pada produk guava jelly drink terpilih meliputi uji kadar zat besi metode AAS (Tee Siong et al., 1989), uji kadar vitamin C metode iodimetri (Sudarmadji et al., 1984), dan uji proksimat yang meliputi kadar air dan abu metode termogravimetri, kadar protein metode Kjeldahl, kadar lemak metode Soxhlet, dan kadar karbohidrat metode by difference (Sudarmadji et al., 1984).

\section{HASIL DAN PEMBAHASAN}

\section{Kadar Zat Besi Kedelai dan Kacang Hijau}

Bahan baku utama yang digunakan sebagai bahan fortifikan zat besi adalah kedelai dan kacang hijau. Hasil analisis kadar zat besi dalam ekstrak kedelai dan kacang hijau dapat dilihat pada Tabel 2.

Tabel 2. Kadar zat besi kedelai dan kacang hijau

\begin{tabular}{lc}
\hline \multicolumn{1}{c}{ Bahan } & Kadar Zat Besi $(\mathrm{ppm})$ \\
\hline Kedelai & $113,856 \pm 18,736^{\mathrm{a}}$ \\
Kacang Hijau & $58,756 \pm 5,919^{\mathrm{b}}$ \\
\hline
\end{tabular}

Ket: Nilai dengan superscript yang berbeda antar baris menunjukan adanya perbedaan nyata pada tingkat kepercayaan 95\% $\quad(\mathrm{p}<0,05)$ berdasarkan uji Independent t-test.

Hasil analisis kadar zat besi dari ekstrak kedelai memiliki jumlah yang lebih besar dibandingkan dengan ekstrak kacang hijau. Kandungan zat besi pada kedelai yang terukur yaitu 113,86 ppm atau $11,39 \mathrm{mg}$ per 100 gram bahan, sedangkan dari kacang hijau sebesar 58,76 ppm atau 5,88 mg per 100 gram bahan. Jumlah fortifikan besi yang ditambahkan dalam produk yaitu 20\% AKG per takaran penyajian. AKG zat besi yang dibutuhkan oleh wanita adalah $18 \mathrm{mg}$ per hari, sehingga banyaknya fortifikan yang 
ditambahkan yaitu 31,61 gram untuk kedelai, dan 61,227 gram untuk kacang hijau.

\section{Analisis Sifat Organoleptik Guava Jelly Drink}

Penentuan produk terpilih dilakukan dengan uji ranking hedonik produk, yaitu berdasarkan sampel yang paling disukai oleh panelis. Jumlah panelis yang digunakan yaitu 30 orang panelis wanita tidak terlatih (mahasiswi program studi Teknologi Pangan Unika Soegijapranata). Hasil analisa ranking hedonik dapat dilihat pada Tabel 3.

Tabel 3. Uji ranking hedonik produk guava jelly drink

\begin{tabular}{lcccc}
\hline \multicolumn{1}{c}{ Atribut } & F1 & F2 & F3 & F4 \\
\hline Rasa & $3,10^{\mathrm{a}}$ & $2,33^{\mathrm{b}}$ & $2,10^{\mathrm{b}}$ & $2,47^{\mathrm{ab}}$ \\
Tekstur & $3,08^{\mathrm{a}}$ & $2,27^{\mathrm{b}}$ & $2,08^{\mathrm{b}}$ & $2,57^{\mathrm{ab}}$ \\
Aroma & $3,40^{\mathrm{a}}$ & $1,93^{\mathrm{b}}$ & $2,20^{\mathrm{b}}$ & $2,47^{\mathrm{b}}$ \\
Warna & $3,20^{\mathrm{a}}$ & $2,67^{\mathrm{ab}}$ & $2,10^{\mathrm{b}}$ & $2,03^{\mathrm{bc}}$ \\
Keseluruhan & $3,33^{\mathrm{a}}$ & $2,23^{\mathrm{b}}$ & $2^{\mathrm{b}}$ & $2,43^{\mathrm{b}}$ \\
Rata-rata & 3,22 & 2,28 & 2,09 & 2,40 \\
\hline
\end{tabular}

Ket: Angka dengan superscript yang berbeda antar baris menunjukan adanya perbedaan nyata pada tingkat kepercayaan 95\% $(\mathrm{p}<0,05)$ berdasarkan uji Friedman dengan uji Wicolxon

F1: guava jelly drink tanpa penambahan fortifikan

F2: guava jelly drink dengan penambahan fortifikan Fe dari kacang hijau

F3: guava jelly drink dengan penambahan fortifikan Fe dari kedelai

F4: guava jelly drink dengan penambahan fortifikan $\mathrm{Fe}$ campuran dari kedelai dan kacang hijau

\section{Rasa guava jelly drink}

Rasa merupakan parameter utama dalam penilaian suatu produk pangan. Berdasarkan hasil analisis Friedman, menunjukkan bahwa perlakuan penambahan fortifikan zat besi dari kedelai (F3) dan kacang hijau (F2) memberikan pengaruh nyata $(\mathrm{p}<0,05)$ pada nilai kesukaan panelis terhadap rasa guava jelly drink. Tetapi hasil tidak berbeda nyata ditunjukkan pada produk F4.
Penggunaan jambu biji merah sebagai bahan utama dalam pembuatan jelly drink memberikan karakteristik rasa yang asam. Adanya penambahan asam sitrat juga memberikan pengaruh terhadap karakteristik rasa yang dihasilkan. Selain itu, penambahan asam sitrat dalam pembuatan jelly drink berfungsi untuk mempertahankan $\mathrm{pH}$ jelly sehingga lebih stabil (Noer, 2006).

\section{Tekstur guava jelly drink}

Atribut tekstur merupakan salah satu ciri utama dari produk jelly drink. Menurut Noer (2006), jelly drink memiliki tekstur yang rapuh sehingga mudah hancur ketika di mulut. Jelly drink memiliki konsentrasi bahan pembentuk gel yang lebih sedikit dibandingkan dengan jelly cup, karena itu jelly drink memiliki konsistensi gel yang lemah, sehingga mudah disedot sebagai minuman.

Berdasarkan hasil analisis Friedman (Tabel 3), diketahui bahwa perlakuan penambahan fortifikan zat besi dari kedelai (F3) dan kacang hijau (F2) memberikan pengaruh nyata $(\mathrm{p}<0,05)$ pada nilai kesukaan panelis terhadap tekstur guava jelly drink. Adapun hasil tidak berbeda nyata ditunjukkan pada produk F4.

\section{Aroma guava jelly drink}

Berdasarkan data Tabel 3, perlakuan penambahan fortifikan zat besi dari kedelai (F3), kacang hijau (F2), dan campuran dari keduanya (F4) memberikan pengaruh nyata $(\mathrm{p}<0,05)$ pada nilai kesukaan panelis terhadap aroma guava jelly drink. Kedelai dan kacang hijau memiliki aroma yang khas, sehingga hal tersebut akan mempengaruhi penilaian panelis terhadap produk.

\section{Warna guava jelly drink}

Berdasarkan data Tabel 3, diketahui bahwa pada perlakuan penambahan fortifikan zat besi dari kedelai (F3) dan campuran dari kedelai dan kacang hijau (F4) memberikan pengaruh nyata $(\mathrm{p}<0,05)$ 
pada nilai kesukaan panelis terhadap warna guava jelly drink. Adapun hasil tidak berbeda nyata ditunjukkan pada produk F2.

Pada atribut warna, nilai tertinggi dihasilkan pada sampel kontrol, karena pada sampel tersebut warna yang dihasilkan tampak lebih cerah dibandingkan dengan sampel lainnya. Fortifikan yang digunakan memiliki warna coklat, sehingga sampel dengan penambahan fortifikan memiliki warna yang sedikit lebih gelap dibandingkan dengan kontrol.

\section{Keseluruhan}

Berdasarkan hasil analisis Friedman pada Tabel 3, diketahui bahwa perlakuan penambahan fortifikan zat besi dari kedelai (F3), kacang hijau (F2), dan campuran keduanya (F4) memberikan pengaruh nyata $(\mathrm{p}<0,05)$ pada nilai kesukaan panelis terhadap keseluruhan guava jelly drink.

\section{Pemilihan Perlakuan Terbaik}

Berdasarkan hasil uji indeks efektifitas, hasil perlakuan yang terbaik yaitu produk guava jelly drink dengan penambahan fortifikan zat besi campuran dari kedelai dan kacang hijau (F4). Produk tersebut selanjutnya dipilih untuk dilakukan analisa selanjutnya.

\section{Analisis Kimiawi Guava Jelly Drink}

Terdapat tiga analisa kimiawi yang dilakukan, yaitu uji kadar zat besi, kadar vitamin $\mathrm{C}$, dan analisa proksimat yang meliputi kadar air, kadar abu, kadar lemak, kadar protein, dan kadar karbohidrat. Kandungan gizi produk guava jelly drink terpilih dapat dilihat pada Tabel 4.

\section{Kadar zat besi}

Adanya penambahan fortifikan zat besi dari campuran ekstrak kedelai dan kacang hijau di dalam guava jelly drink memberikan pengaruh yang nyata $(\mathrm{p}<0,05)$. Hal ini dapat dilihat pada Tabel 4 yang menunjukkan hasil peningkatan kandungan zat besi yang cukup signifikan dibandingkan dengan kontrol. Batas asupan zat besi pada tubuh yaitu 40-45 $\mathrm{mg}$ per hari, sedangkan jumlah zat besi yang terkandung di dalam guava jelly drink dengan penambahan fortifikan zat besi yaitu sebesar 13,05 mg, sehingga produk tersebut aman untuk dikonsumsi karena tidak melebihi batas asupan zat besi.

\section{Kadar vitamin $C$}

Jambu biji merah merupakan salah satu buah dengan kandungan vitamin $\mathrm{C}$ tertinggi. Dalam penelitiannya, Nair et al. (2013) mengungkapkan bahwa dengan mengonsumsi $100 \mathrm{~g}$ buah jambu biji segar, mampu meningkatkan penyerapan zat besi

Tabel 4. Kandungan gizi produk guava jelly drink terpilih

\begin{tabular}{lcr}
\hline \multicolumn{1}{c}{ Kandungan } & \multicolumn{2}{c}{ Perlakuan } \\
\cline { 2 - 3 } \multicolumn{1}{c}{ Gizi } & Kontrol & Penambahan Fe \\
\hline Air (\%) & $86,103 \pm 0,228^{\mathrm{a}}$ & $87,473 \pm 0,158^{\mathrm{b}}$ \\
Abu (\%) & $0,143 \pm 0,04^{\mathrm{a}}$ & $0,353 \pm 0,048^{\mathrm{b}}$ \\
Lemak (\%) & $0,275 \pm 0,078^{\mathrm{a}}$ & $0,195 \pm 0,048^{\mathrm{a}}$ \\
Protein (\%) & $0,154 \pm 0,058^{\mathrm{a}}$ & $0,306 \pm 0,079^{\mathrm{b}}$ \\
Karbohidrat (\%) & $13,325 \pm 0,32^{\mathrm{a}}$ & $11,673 \pm 0,224^{\mathrm{b}}$ \\
Zat Besi (ppm) & $81,935 \pm 13,947^{\mathrm{a}}$ & $130,483 \pm 11,512^{\mathrm{b}}$ \\
Vitamin C (mg) & $90,640 \pm 10,133^{\mathrm{a}}$ & $90,787 \pm 13,243^{\mathrm{a}}$ \\
\hline
\end{tabular}

Ket: Nilai dengan superscript yang berbeda antar baris menunjukan adanya perbedaan nyata pada tingkat kepercayaan $95 \%(\mathrm{p}<0,05)$ berdasarkan uji Independent $t$-test. 
hingga 2 kali lipat. Adanya proses pemanasan dalam pembuatan guava jelly drink, menyebabkan penurunan jumlah kandungan vitamin $\mathrm{C}$ jambu biji. Berdasarkan hasil analisis kimiawi pada Tabel 4 diketahui bahwa kandungan vitamin C pada guava jelly drink kontrol adalah 90,64 mg, sedangkan pada guava jelly drink dengan penambahan fortifikan adalah 90,787 mg.

\section{Kadar air}

Berdasarkan hasil pada Tabel 4, diketahui bahwa kadar air guava jelly drink dengan penambahan fortifikan zat besi campuran dari kedelai dan kacang hijau adalah 87,48\%, lebih tinggi dibandingkan guava jelly drink tanpa penambahan fortifikan yaitu sebesar 86,1\%. Menurut Gamman \& Sherrington (1994), untuk menghasilkan konsistensi gel yang lembut, kadar air jelly drink berkisar di atas $84 \%$, sehingga dapat dengan mudah diminum

\section{Kadar $a b u$}

Kadar abu guava jelly drink dengan penambahan fortifikan zat besi campuran dari kedelai dan kacang hijau adalah $0,35 \%$, dan pada guava jelly drink tanpa penambahan fortifikan zat besi adalah $0,14 \%$. Adanya penambahan fortifikan besi memberikan perbedaan nyata terhadap kandungan mineral total guava jelly drink. Hal ini didukung dengan Sudarmadji et al. (1984), bahwa tingginya kadar abu menunjukkan tingginya kandungan mineral dalam produk tersebut, yakni dalam penelitian ini karena adanya fortifikasi mineral Fe. Zat besi merupakan salah satu jenis mineral esensial bagi tubuh yang berperan dalam proses hemopoesis (pembentukan darah). Di dalam tubuh, zat besi disimpan di dalam hati dalam bentuk feritin dan haemosiderin (WHO, 2001).

\section{Kadar lemak}

Berdasarkan hasil pada Tabel 4, kandungan lemak pada guava jelly drink dengan penambahan fortifikan zat besi campuran dari kedelai dan kacang hijau tidak memberikan hasil yang berbeda nyata dengan sampel tanpa penambahan fortifikan. Pada proses ekstraksi zat besi terdapat tahap penyaringan dengan menggunakan kertas saring. Lemak yang terlarut dalam pelarutpun tidak ikut tersaring. Selain itu bahan yang digunakan dalam pembuatan guava jelly drink bukanlah sumber lemak, sehingga kandungan lemak pada sampel pun cukup rendah. Menurut aturan BPOM (2005) disebutkan bahwa produk pangan akan dikatakan bebas lemak jika mengandung 0,5 gram lemak per 100 gram bahan. Dalam penelitian ini, guava jelly drink terpilih mengandung lemak $0,2 \%$ atau 0,2 gram lemak per 100 gram guava jelly drink. Hal tersebut membuktikan bahwa produk guava jelly drink merupakan produk yang rendah lemak.

\section{Kadar protein}

Kedelai dan kacang hijau merupakan sumber protein nabati yang baik. Berdasarkan data USDA, jumlah kandungan protein dalam kedelai mencapai 36,49\%, sedangkan dalam kacang hijau mencapai 23,86\%. Oleh karena itu, kadar protein produk guava jelly drink dengan penambahan fortifikan zat besi campuran antara kedelai dan kacang hijau dua kali lipat lebih tinggi dibandingkan dengan guava jelly drink tanpa penambahan fortifikan.

\section{Kadar karbohidrat}

Hasil pada Tabel 4, menunjukkan bahwa kadar karbohidrat guava jelly drink tanpa penambahan fortifikan lebih tinggi dibandingkan dengan guava jelly drink dengan penambahan fortifikan zat besi campuran dari kedelai dan kacang hijau. Analisa karbohidrat dilakukan dengan menggunakan metode by difference, yaitu penjumlahan matematis karbohidrat dikurangi komponen lain dalam bahan pangan (Sudarmadji et al., 1984). Jumlah 
kadar air pada guava jelly drink tanpa penambahan fortifikan lebih rendah dibandingkan dengan guava jelly drink dengan penambahan fortifikan, sehingga hal tersebut mempengaruhi perhitungan kadar karbohidrat berdasarkan metode by difference.

\section{KESIMPULAN}

Dengan metode maserasi etanol $30 \%$, kandungan zat besi dari kedelai dan kacang hijau yang terukur secara berurutan yaitu 113,86 ppm dan 58,76 ppm. Berdasarkan hasil analisa organoleptik, produk guava jelly drink yang disukai oleh panelis yaitu produk guava jelly drink dengan penambahan fortifikan zat besi campuran dari kedelai dan kacang hijau. Secara keseluruhan, kandungan zat gizi pada guava jelly drink dengan penambahan fortifikan zat besi campuran dari kedelai dan kacang hijau yaitu $87,473 \%$ air, $0,353 \%$ abu, $0,195 \%$ lemak, $0,306 \%$ protein, $11,673 \%$ karbohidrat, $130,483 \mathrm{ppm}$ zat besi, dan 90,787 $\mathrm{mg}$ vitamin $\mathrm{C}$.

\section{UCAPAN TERIMAKASIH}

Ucapan terimakasih ditujukan kepada PT Indofood Sukses Makmur Tbk dalam program Indofood Reset Nugraha (IRN) periode 2016/2017 yang telah mendukung secara finansial terlaksananya penelitian ini.

\section{DAFTAR PUSTAKA}

Benito, P. and D. Miller. 1998. Iron Absorption and bioavailability: An Updated review. J. Nutrition Research, 18 (3): 581-603.

BPOM RI. 2005. Peraturan Kepala Badan Pengawasan Obat dan Makanan Republik Indonesia Nomor HK.00.06.51.0475 tentang Pedoman Pencantuman Informasi Nilai Gizi Pada Label Pangan. Kepala BPOM, Jakarta.
Gaman, P.M. dan KB Sherrington. 1994. Ilmu Pangan Pengantar Ilmu Pangan Nutrisi dan Mikrobiologi. UGM Press, Yogyakarta.

Nair, K. M., G. N.V. Brahmam, M.S. Radhika, R.C. Dripta, P. Ravinder, N. Balakrishna, Z. Chen, K.M. Hawthorne, and S.A. Abrams. 2013. Inclusion of guava enhances non-heme iron bioavailability but not fractional zinc absorption from a rice-based meal in adolescents. J. Nutr., 143: 852-858.

Noer H. 2006. Hidrokoloid dalam pembuatan jelly drink. Food Review, 1 (2).

Nursuchita, S., H. A. Thai' in, D. M. Putri, D. N. Utami and A. P. Ghani. 2014. Antianemia activity of parkia speciosa hassk seed ethanolic extract. Traditional Medicine Journal, 19 (2): 49-54.

Ruel, M.T. 2001. Can Food-Based Strategies Help Reduce Vitamin A and Iron Deficiencies? A Review of Recent Evidence. International Food Policy Research Institute, Washington DC.

Sudarmadji, S., B. Haryono, dan Suhardi. 1984. Analisa Bahan Makanan dan Pertanian Edisi Ketiga. Liberty, Yogyakarta.

Tee, E.S., S.c. Khor and S. S. Mizura. 1989. Determination of iron in foods by the atomic absorption spectrophotometric and calorimetric methods. Pertanika, 12 (3): 313-322.

USDA [United States Department of Agriculture]. 2017. National Nutrient Database for Standard Reference (https://ndb.nal.usda.gov/ndb/search/list). [Diakses Tanggal 12 Januari 2017]

WHO [World Health Organization]. 2001. Iron Deficiency Anaemia, Assessment, Prevention, and Control: A Guide for Programme Managers. World Health Organization, Geneva.

WHO [World Health Organization]. 2006. Adolescent Nutrition: A Review of the Situation in Selected South-East Asian Countries. WHO Region Office for South-East Asia, New Delhi. 